\title{
ANALYSIS OF RC FRAME WITH AND WITHOUT MASONRY INFILL WALL WITH DIFFERENT STIFFNESS WITH OUTER CENTRAL OPENING
}

\author{
Mohammad H. Jinya ${ }^{1}$, V. R. Patel $^{2}$ \\ ${ }^{I}$ P.G. Student, Applied Mechanics Department, M. S. University of Baroda, Vadodara, India. \\ ${ }^{2}$ Assistant Professor, Applied Mechanics Department, M. S. University of Baroda, Vadodara, India.
}

\begin{abstract}
In reinforced concrete frame building, masonry wall are generally used in as infills and specified by architects as partitions in such a way that they do not contribute to the vertical gravity load-bearing capacity of the structure. Infill walls protect the inside of the buildings from the environment hazards and create separation insides. In addition to this infills have a considerable strength and stiffness and they have significant effect on the seismic response of the structural systems. Mostly two common structural damages observed caused by masonry infill walls in earthquakes i.e soft stories and short columns. In office or residential building outer side central opening are used. In this case central opening are provided in periphery wall with different percentage i.e. $15 \%$ and $25 \%$ and brick compressive strength are used as per IS : 1905-1987 i.e. 5.0 and $12.5 \mathrm{~N} / \mathrm{mm}^{2}$ and Brick Masonry strength is 0.50 and 1.06N/mm ${ }^{2}$. In ETABS software G+9 R.C.C framed building models has been prepared, Seismic coefficient method(SCM) and time-history(TH) has been performed for analysis as per IS 1893:2002. Story displacement, base shear, story drift, axial force with and without soft story considering effect of infill walls with different percentage of opening are the parameters considered in this study. For Macro model, Equivalent diagonal strut (EDS) method is used to find out width of strut using FEMA approach method. The results of bare frame, soft story and infill wall panel are discussed and conclusions are made in this studies.
\end{abstract}

Key Words: Base shear, Displacement, Equivalent Diagonal Strut, Storey Drift, Soft storey.

\section{INTRODUCTION}

In RC frame brick walls is just architectural point of view and to make partition and other aspect. In multistory buildings, the ordinarily occurring vertical loads i.e. dead or alive, do not cause much of a effects, but the lateral loads due to wind or earthquake tremors are a matter of great concern and need special consideration in the design of buildings. These lateral forces can produce the critical stress in a structure, set up undesirable vibrations, and in addition, cause lateral sway of the structure which can reach a stage of discomfort to the occupants. In many countries situated in seismic regions, reinforced concrete frames are infilled fully or partially by brick masonry panels with or without openings. Although the infill panels significantly enhance both the stiffness and strength of the frame, their contribution is often not taken into account because of the lack of knowledge of the composite behavior of the frame and the infill. During the elastic response phase, the presence of brick infill walls increases in plane lateral stiffness of the structure and reduced its fundamental period, and as a result leads to larger shear forces.
In residential building $\mathrm{RC}$ frame structure are infill by brick panels on all four sides and resisting the lateral earthquake loads on building. By experimentally it has been shown that brick walls have high initial lateral stiffness (Moghaddam and Dowling 1987, Drysdale et al. 1999, Paulay and Priestley 1992,). Hence masonry infills in RC frames different lateral load transfer mechanism of the structure from predominant frame action to predominant truss action (Murty and Jain 2000). Shown in Figure 1 below. Thus it is responsible for increase in axial forces in the RC frame.

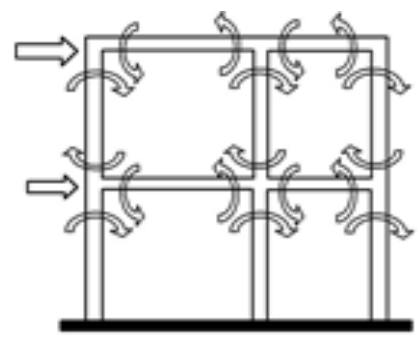

(a) Predominant frame action

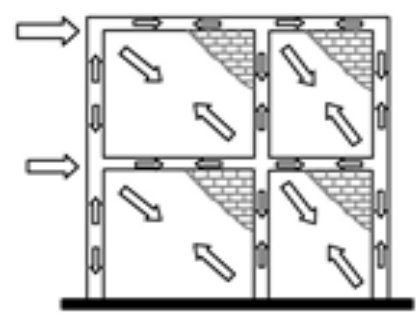

(b) Predominant truss action
Fig -1: Change in lateral-load transfer mechanism due to masonry infill (Murty and Jain 2000) 


\section{LITERATURE REVIEW}

From several research paper studies it shows that Equivalent diagonal strut method is used for modeling the brick infill wall to easy represent the effect of inplane during lateral load and its equations for Equivalent diagonal strut width for full infill given by various researchers are,

In 1961 Holmes, infill panel $\mathrm{w}=\mathrm{dz} / 3 \quad$ where, $\mathrm{dz}=$ Diagonal length of

In 1962 Equivalent diagonal strut according to Smith,

$$
\begin{aligned}
& W_{o}=\sqrt{\alpha_{h}^{2}+\alpha_{L}^{2}} \\
& \frac{\alpha_{h}}{L^{\prime}}=\frac{\pi}{2} \cdot \frac{1}{\lambda_{h} \cdot L^{\prime}} \quad \lambda_{\mathrm{h}} \cdot \mathrm{L}^{\prime}=L^{\prime} \cdot \sqrt{\frac{E_{\text {panel }} \cdot t}{4 \cdot E_{p} \cdot I_{p} \cdot h} \operatorname{sen}(2 \theta)} \\
& \frac{\alpha_{L}}{L^{\prime}}=\pi \cdot \frac{1}{\lambda_{L} \cdot L^{\prime}} \quad \lambda_{\mathrm{L}} \cdot L^{\prime}=L^{\prime} \cdot \sqrt{\frac{E_{\text {panel }} \cdot t}{4 \cdot E_{p} \cdot I_{b} \cdot L} \operatorname{sen}(2 \theta)}
\end{aligned}
$$

In 1969 Smith and Carter,

$$
\begin{array}{r}
w=0.58\left(\frac{1}{H}\right)^{-0.445}\left(\lambda_{h} H^{\prime}\right)^{0.335 d_{z}\left(\frac{1}{H}\right)^{0.064}} \\
\lambda_{h}=\sqrt[4]{\frac{E_{z} t \sin 2 \theta}{4 E_{b} I_{s} H}}
\end{array}
$$

In 1971 Mainstone, $\mathrm{w}=0.175 \mathrm{dz}\left(\lambda_{\mathrm{h}} \mathrm{H}^{\prime}\right)^{-0.4}$

In 1984 Liaw and Kwan, $\mathrm{w}=(0.95 \mathrm{H} \cos \theta) / \sqrt{\lambda} \mathrm{hH}^{\prime}$

In 1992 Paulay \& Priestley, $\mathrm{w}=\mathrm{dz} / 4$

\section{RESEARCH OBJECTIVES}

The main objective of this paper is to simplify the analysis concept of the building industry. And also carry out the effect of brick masonry infilled walls for the static linear analysis and Time history analysis of the R.C.C high rise building with single diagonal strut approach as per IS 1893:2002 and IS 456:2000. The result would be carried out and compare for G+9 story R.C.C. building.

\begin{tabular}{|c|c|}
\hline Story $=$ & $\mathrm{G}+84 \times 3$ bay \\
\hline Ground floor height $=$ & $3.0 \mathrm{~m}$ \\
\hline Typ. story height $=$ & $2.9 \mathrm{~m}$ \\
\hline Basement height $=$ & $3.0 \mathrm{~m}$ \\
\hline Beam $=$ & $230 \times 450 \mathrm{~mm}$ \\
\hline Column $=$ & $500 \times 500 \mathrm{~mm}$ \\
\hline Spacing of frame $\mathrm{X}$ direction $=$ & $3 \mathrm{~m}$ \\
\hline Spacing of frame Y direction= & $3 \mathrm{~m}$ \\
\hline Live load $=$ & $\begin{array}{l}1.5 \mathrm{kn} / \mathrm{m}^{2} \text { for terrace } \\
3.0 \mathrm{kn} / \mathrm{m}^{2} \text { for typ floor }\end{array}$ \\
\hline Dead load= & $\begin{array}{l}2.0 \mathrm{kn} / \mathrm{m}^{2} \text { for terrace } \\
1.0 \mathrm{kn} / \mathrm{m}^{2} \text { for typ floor }\end{array}$ \\
\hline Response Reduction Factor, $\mathrm{R}=$ & 3 for SMRF \\
\hline Importance factor, $\mathrm{I}=$ & 1.0 \\
\hline Type of soil= & Medium \\
\hline Damping of structure $=$ & $5 \%$ \\
\hline Grade of concrete $=$ & M30 \\
\hline Steel= & Fe 415 \\
\hline Density of concrete $=$ & $25 \mathrm{kn} / \mathrm{m}^{3}$ \\
\hline Density of brick wall= & $20 \mathrm{kn} / \mathrm{m}^{3}$ \\
\hline $\begin{array}{l}\text { Modulus of elasticity of } \\
\text { concrete, } \mathrm{Ec}=\end{array}$ & $27.386 \times 10^{6} \mathrm{kn} / \mathrm{m}^{2}$ \\
\hline $\begin{array}{l}\text { Modulus of elasticity masonry, } \\
\text { Em= }\end{array}$ & $\begin{array}{l}\text { 1) } 0.275 \times 10^{6} \mathrm{kn} / \mathrm{m}^{2} \\
\text { 2) } 0.583 \times 10^{6} \mathrm{kn} / \mathrm{m}^{2}\end{array}$ \\
\hline Thick. of outer Brick wall= & $115 \mathrm{~mm}$ \\
\hline Thick. of inner Brick wall= & $115 \mathrm{~mm}$ \\
\hline Thick. of slab $=$ & $125 \mathrm{~mm}$ \\
\hline Poisson ratio of concrete $=$ & 0.2 \\
\hline Poisson ratio of brick wall= & 0.17 \\
\hline Seismic zone $=$ & $\mathrm{V}$ \\
\hline$Z=$ & 0.36 \\
\hline Time history & Bhuj_Ahmedabad \\
\hline
\end{tabular}

\section{METHOD OF ANALYSIS OF THE BRICK INFILL WALL}

\subsection{Data Taken}

Table -1: Data for Building

\subsection{Types of Model}

Table -2: Types of Model

\begin{tabular}{|c|c|}
\hline $\begin{array}{c}\text { ID } \\
\text { (The First value } \\
\text { indicates masonry } \\
\text { comp. stress, } \\
\text { N/mm } \mathbf{m}^{2}\end{array}$ & Description \\
\hline $0.5 \mathrm{BFGSS} 15 \%$ & $\begin{array}{c}\text { Bare frame ground soft story with } \\
15 \% \text { outer central opening }\end{array}$ \\
\hline $0.5 \mathrm{SFGSS} 15 \%$ & $\begin{array}{c}\text { Strut frame ground soft story with } \\
15 \% \text { outer central opening }\end{array}$ \\
\hline $1.06 \mathrm{BFGSS} 15 \%$ & $\begin{array}{c}\text { Bare frame ground soft story with } \\
15 \% \text { outer central opening }\end{array}$ \\
\hline $1.06 \mathrm{SFGSS} 15 \%$ & $\begin{array}{c}\text { Strut frame ground soft story with } \\
15 \% \text { outer central opening }\end{array}$ \\
\hline $0.5 \mathrm{BFGSS} 25 \%$ & $\begin{array}{c}\text { Bare frame ground soft story with } \\
25 \% \text { outer central opening }\end{array}$ \\
\hline $0.5 \mathrm{SFGSS} 25 \%$ & $\begin{array}{c}\text { Strut frame ground soft story with } \\
25 \% \text { outer central opening }\end{array}$ \\
\hline $1.06 \mathrm{BFGSS} 25 \%$ & $\begin{array}{c}\text { Bare frame ground soft story with } \\
25 \% \text { outer central opening }\end{array}$ \\
\hline
\end{tabular}




\begin{tabular}{|c|c|}
\hline 1.06 SFGSS25\% & $\begin{array}{c}\text { Strut frame ground soft story with } \\
25 \% \text { outer central opening }\end{array}$ \\
\hline $0.5 \mathrm{BFWSS} 15 \%$ & $\begin{array}{c}\text { Bare frame without soft story with } \\
15 \% \text { outer central opening }\end{array}$ \\
\hline $0.5 \mathrm{SFWSS} 15 \%$ & $\begin{array}{c}\text { Strut frame without soft story } \\
\text { with 15\% outer central opening }\end{array}$ \\
\hline $1.06 \mathrm{BFWSS} 15 \%$ & $\begin{array}{c}\text { Bare frame without soft story with } \\
15 \% \text { outer central opening }\end{array}$ \\
\hline $1.06 \mathrm{SFWSS} 15 \%$ & $\begin{array}{c}\text { Strut frame without soft story } \\
\text { with } 15 \% \text { outer central opening }\end{array}$ \\
\hline $0.5 \mathrm{BFWSS} 25 \%$ & $\begin{array}{c}\text { Bare frame without soft story with } \\
25 \% \text { outer central opening }\end{array}$ \\
\hline $0.5 \mathrm{SFWSS} 25 \%$ & $\begin{array}{c}\text { Strut frame without soft story } \\
\text { with } 25 \% \text { outer central opening }\end{array}$ \\
\hline $1.06 \mathrm{BFWSS} 25 \%$ & $\begin{array}{c}\text { Bare frame without soft story } \\
\text { with } 25 \% \text { outer central opening } \\
\text { Strut frame without soft story } \\
\text { with 25\% outer central opening }\end{array}$ \\
\hline 1.06 SFWSS25\%
\end{tabular}

\subsection{FEMA Approach}

Equivalent diagonal strut method is used for modeling the brick infill wall according to FEMA273.The infill frame in this model was assumed as an equivalent diagonal strut with frame the pin joint(hinge joint) at the corners of the RC frame(See Fig.5).

In this method the brick infill wall replaced by diagonal strut. The frame is analyzed as truss element.

The equivalent diagonal strut width is given as:

$$
\mathrm{w}=0.175\left(\lambda_{1} \mathrm{~h}_{\mathrm{col}}{ }^{-0.4} \mathrm{r}_{\text {inf................. }} \mathrm{q}^{\mathrm{n}} 1\right.
$$

Where, $\quad \lambda_{1}=$

$$
\left\{\frac{E_{m e} * t_{i r}}{4 E_{e f} * I_{c}}\right.
$$

\subsection{Modelling of Brick Infill Wall}

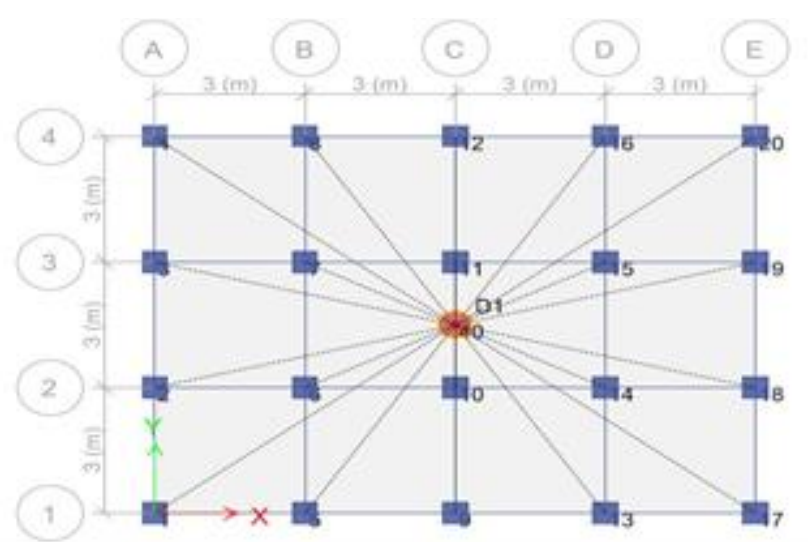

Fig -2: Plan

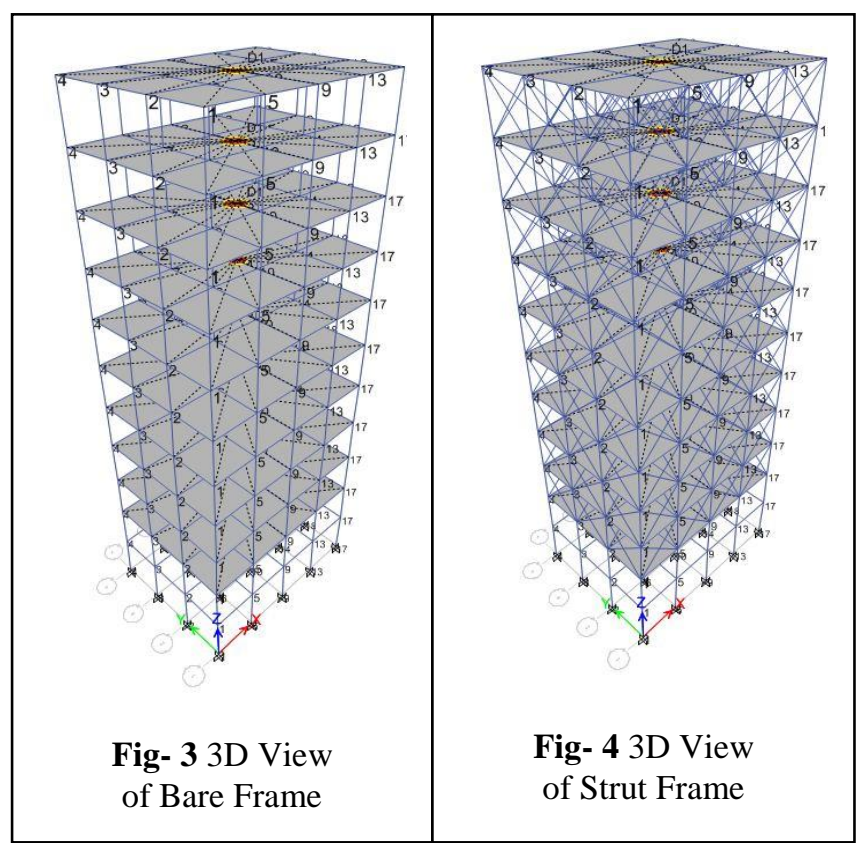

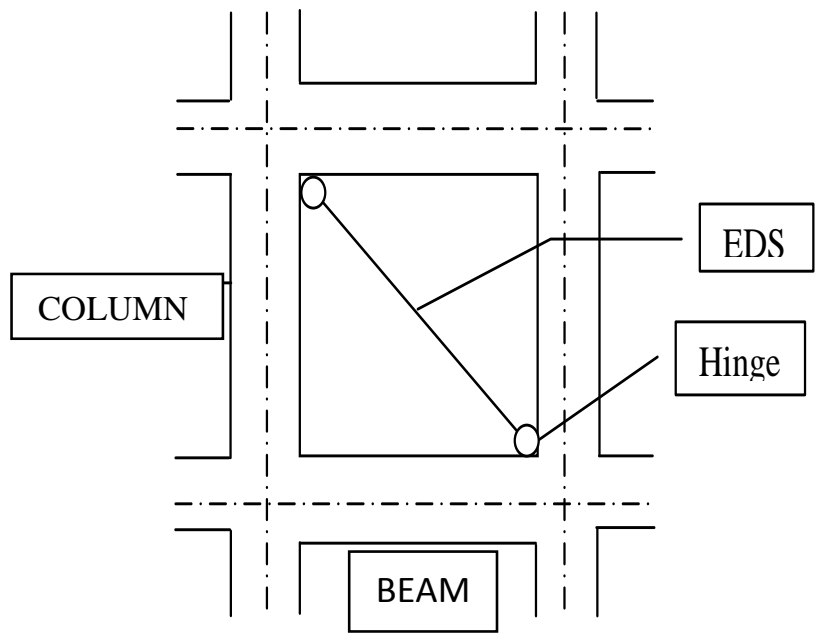

Fig- 5 Diagonal strut with pinned joint

And

$\mathrm{h}_{\mathrm{col}} \quad=$ Column height between centerlines of beams, $\mathrm{m}$

$\mathrm{h}_{\text {inf }} \quad=$ Height of infill panel, $\mathrm{m}$

$\mathrm{E}_{\mathrm{fe}} \quad=$ Expected modulus of elasticity of frame material, $\mathrm{kn} / \mathrm{m}^{2}$

$\mathrm{E}_{\mathrm{me}} \quad=$ Expected modulus of elasticity of infill material, $\mathrm{kn} / \mathrm{m}^{2}$

$\mathrm{I}_{\mathrm{col}} \quad=$ Moment of inertia of column, $\mathrm{m}^{4}$

$\mathrm{L}_{\text {inf }} \quad=$ Length of infill panel, $\mathrm{m}$

$\mathrm{r}_{\mathrm{inf}} \quad=$ Diagonal length of infill panel, $\mathrm{m}$

$\mathrm{t}_{\mathrm{inf}} \quad=$ Thickness of infill panel and equivalent strut, $\mathrm{m}$

$\theta \quad=$ Angle whose tangent is the infill height-to-length aspect ratio, radians

$\lambda_{1}=$ Coefficient used to determine equivalent width of infill strut 


\subsection{Strut Reduction Factor}

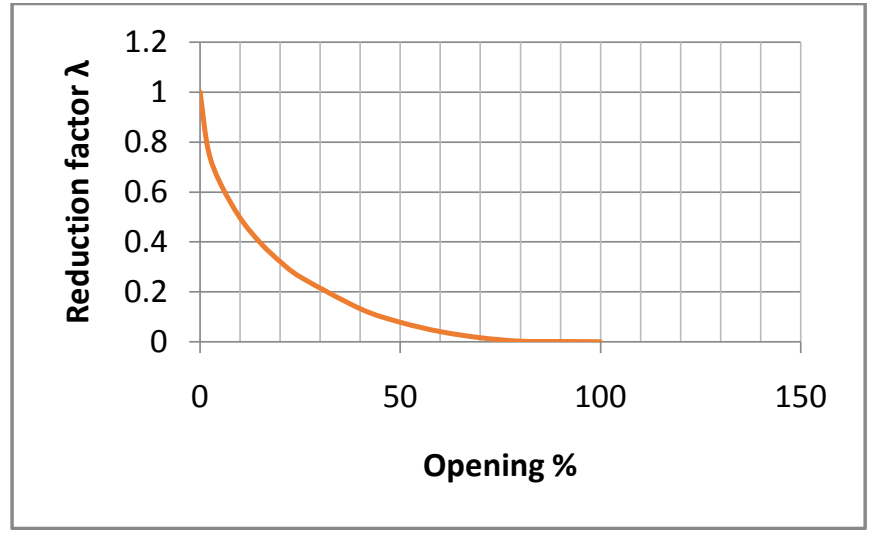

Reduction factor

$$
\lambda=1-2 \alpha_{\mathrm{w}}^{0.54}+\alpha_{\mathrm{w}}^{1.14}
$$

The above coefficient $(K)$ could be used to find the equivalent width of a strut for the case of an infill with opening by multiplying the results of Eqns. 1 above for central opening.

\subsection{Modulus of elasticity of brick masonry}

In lieu of prism tests, values for the modulus of elasticity of masonry in compression shall be taken as, 550 times the expected masonry compressive strength, $f_{m e}$.

i) Compressive strength, $f_{m e}=0.5 \mathrm{MPa}$

(IS 1905:1998, Table-8)

$\mathrm{Em}=550 \times f_{m e}=550 \times 0.5 \times 10^{3}=0.275 \times 10^{6} \mathrm{kn} / \mathrm{m}^{2}$

ii) Compressive strength, $f_{m e}=1.06 \mathrm{MPa}$

(IS 1905:1998, Table-8)

$\mathrm{Em}=550 \times f_{m e}=550 \times 1.06 \times 10^{3}=0.583 \times 10^{6} \mathrm{kn} / \mathrm{m}^{2}$

\subsection{Fundamental Natural Period of Vibration, (Ts)}

$\mathrm{Ts}=0.09 \mathrm{~h} / \mathrm{sqrt}(\mathrm{d})$

$\mathrm{Tx}=0.8314 \mathrm{~s}, \mathrm{Ty}=0.96 \mathrm{~s}$

Where, $\mathrm{h}=$ Height of building, in $\mathrm{m}$

$\mathrm{d}=$ Base dimension of the building at the plinth level, in $\mathrm{m}$

\subsection{Average Response Acceleration Coefficient}

$(\mathrm{Sa} / \mathrm{g}) \mathrm{x}=1.36 / \mathrm{T}=1.635826$

$(\mathrm{Sa} / \mathrm{g}) \mathrm{y}=1.36 / \mathrm{T}=1.416667$

\section{RESULT AND DISCUSSION}

\subsection{Base Shear}

The design base shear $\mathrm{V}_{\mathrm{b}}$ as per IS: 1893 shall be calculated by following formula,

$$
\mathrm{Vb}=\mathrm{Ah} \times \mathrm{W}
$$

Where, $\quad \mathrm{Ah}_{\mathrm{x}, \mathrm{y}}=\mathrm{ZIS} / 2 \mathrm{RG}$

$\mathrm{Ah}_{\mathrm{x}}=0.069949$

$\mathrm{Ah}_{\mathrm{y}}=0.049461$

Table -3: Base shear

\begin{tabular}{|c|c|c|}
\hline \multicolumn{3}{|c|}{ BASE SHEAR IN X-DIRECTION(KN) } \\
\hline ID & SCM & TH \\
\hline 0.5 BFGSS15\% & 1549.31 & 1222.84 \\
\hline 0.5 SFGSS15\% & 1549.31 & 1178.59 \\
\hline 1.06 BFGSS15\% & 1549.31 & 1222.84 \\
\hline 1.06 SFGSS15\% & 1549.31 & 1379.87 \\
\hline $0.5 B F G S S 25 \%$ & 1519.63 & 1196.86 \\
\hline 0.5 SFGSS25\% & 1519.63 & 1155.00 \\
\hline 1.06 BFGSS25\% & 1519.63 & 1196.86 \\
\hline 1.06 SFGSS25\% & 1519.63 & 1348.81 \\
\hline 0.5 BFWSS15\% & 1595.76 & 1233.61 \\
\hline 0.5 SFWSS15\% & 1595.77 & 1202.23 \\
\hline 1.06 BFWSS15\% & 1595.76 & 1233.61 \\
\hline 1.06 SFWSS15\% & 1595.77 & 1693.92 \\
\hline $0.5 B F W S S 25 \%$ & 1566.01 & 1208.23 \\
\hline $0.5 S F W S S 25 \%$ & 1566.01 & 1186.65 \\
\hline 1.06 BFWSS25\% & 1566.01 & 1208.23 \\
\hline 1.06 SFWSS25\% & 1566.01 & 1652.86 \\
\hline
\end{tabular}

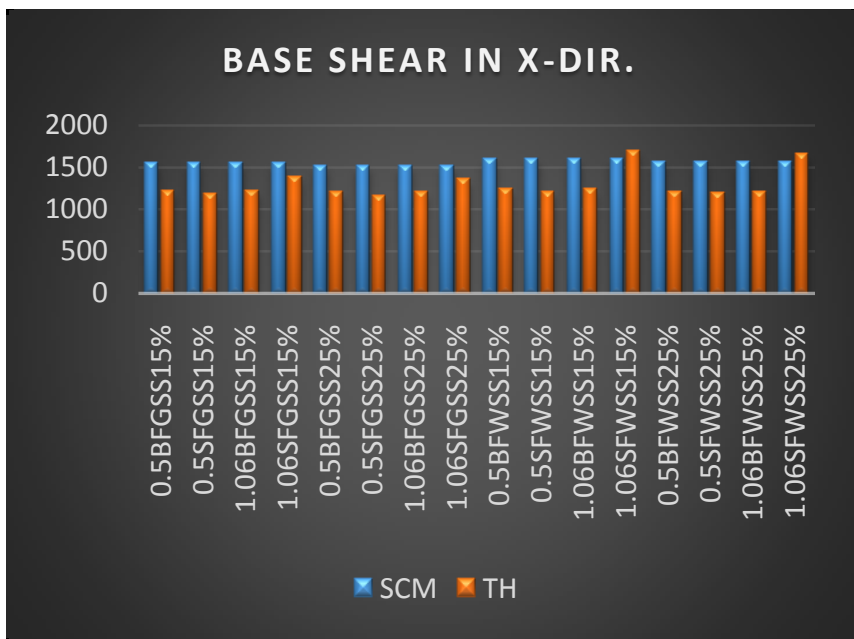

Chart -1: Base shear at base in X Direction (Kn)

We can conclude from this analysis that with increase in stiffness of infill wall base shear of building also increase thus stiffness of wall is should be minimum.

\subsection{Displacement}


Table -4: Displacement at the top level

\begin{tabular}{|c|c|c|c|}
\hline \multicolumn{4}{|c|}{ DISPLACEMENT AT ROOF LEVEL IN MM } \\
\hline $\begin{array}{c}\text { SR } \\
\text { NO. }\end{array}$ & ID & SCM & TH \\
\hline 1 & 0.5 BFGSS15\% & 51.2 & 31.55 \\
\hline 2 & 0.5 SFGSS15\% & 44.59 & 27.37 \\
\hline 3 & 1.06 BFGSS15\% & 51.2 & 31.55 \\
\hline 4 & 1.06 SFGSS15\% & 39.42 & 31.21 \\
\hline 5 & 0.5 BFGSS25\% & 50.28 & 31.45 \\
\hline 6 & 0.5 SFGSS25\% & 44.34 & 27.64 \\
\hline 7 & 1.06 BFGSS25\% & 50.28 & 31.45 \\
\hline 8 & 1.06 SFGSS25\% & 39.56 & 31.19 \\
\hline 9 & 0.5 BFWSS15\% & 52.7 & 31.69 \\
\hline 10 & 0.5 SFWSS15\% & 44.74 & 28.95 \\
\hline 11 & 1.06 BFWSS15\% & 52.7 & 31.69 \\
\hline 12 & 1.06 SFWSS15\% & 38.63 & 32.58 \\
\hline 13 & $0.5 B F W S S 25 \%$ & 51.78 & 31.6 \\
\hline 14 & 0.5 SFWSS25\% & 44.52 & 29.19 \\
\hline 15 & 1.06 BFWSS25\% & 51.78 & 31.6 \\
\hline 16 & 1.06 SFWSS25\% & 38.81 & 32.61 \\
\hline
\end{tabular}

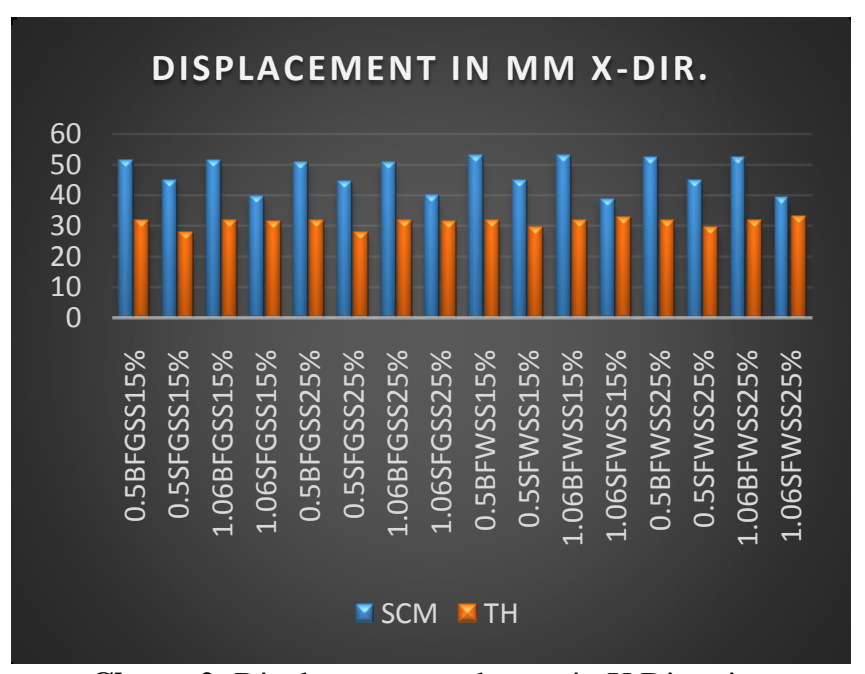

Chart -2: Displacement at the top in X Direction

The displacement in $\mathrm{X}$ direction for diff. models are shown in Graph 2. From graph it can be concluded that with increase in stiffness of infill wall displacement of building decreased by $12 \%$ to $25 \%$ ( see Table 4) in Static and Dynamic analysis.

\subsection{Story Drift}

The drift value for SCM and TH analysis results are shown in followings different chart in $\mathrm{mm}$ (see Chart 3 to 6).

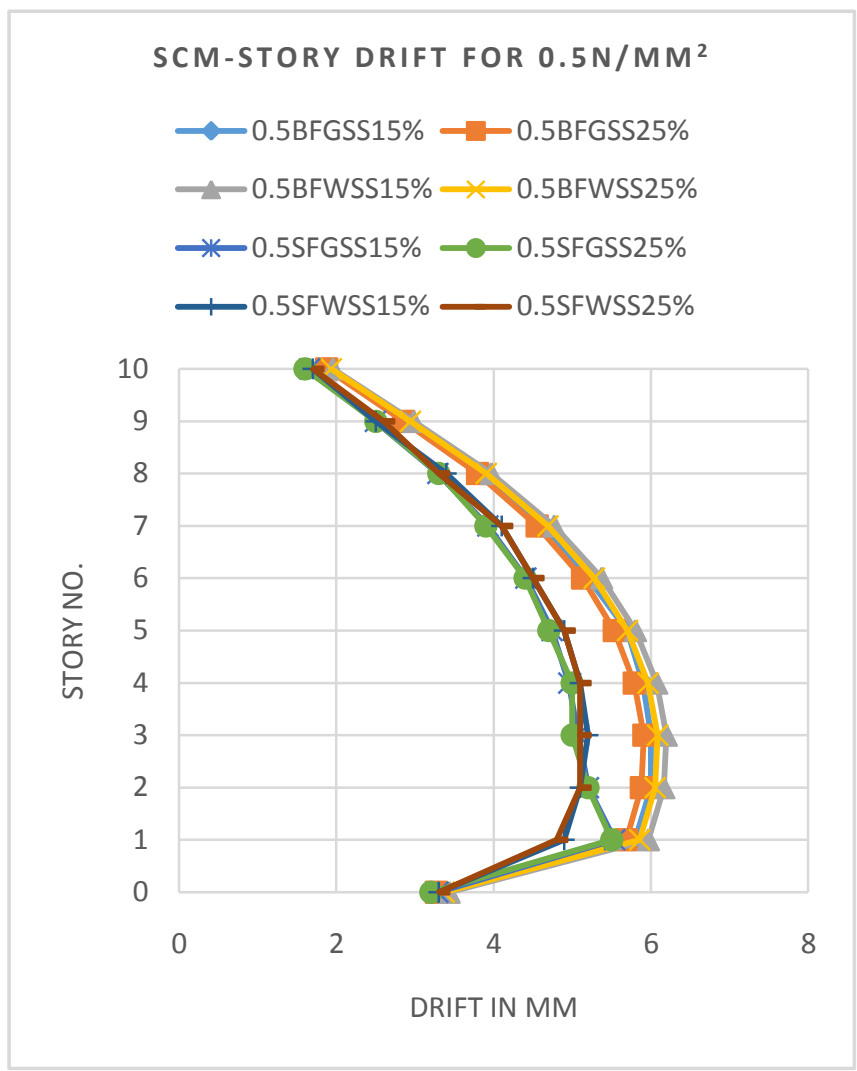

Chart-3: Story Drift for SCM in X direction (0.5)

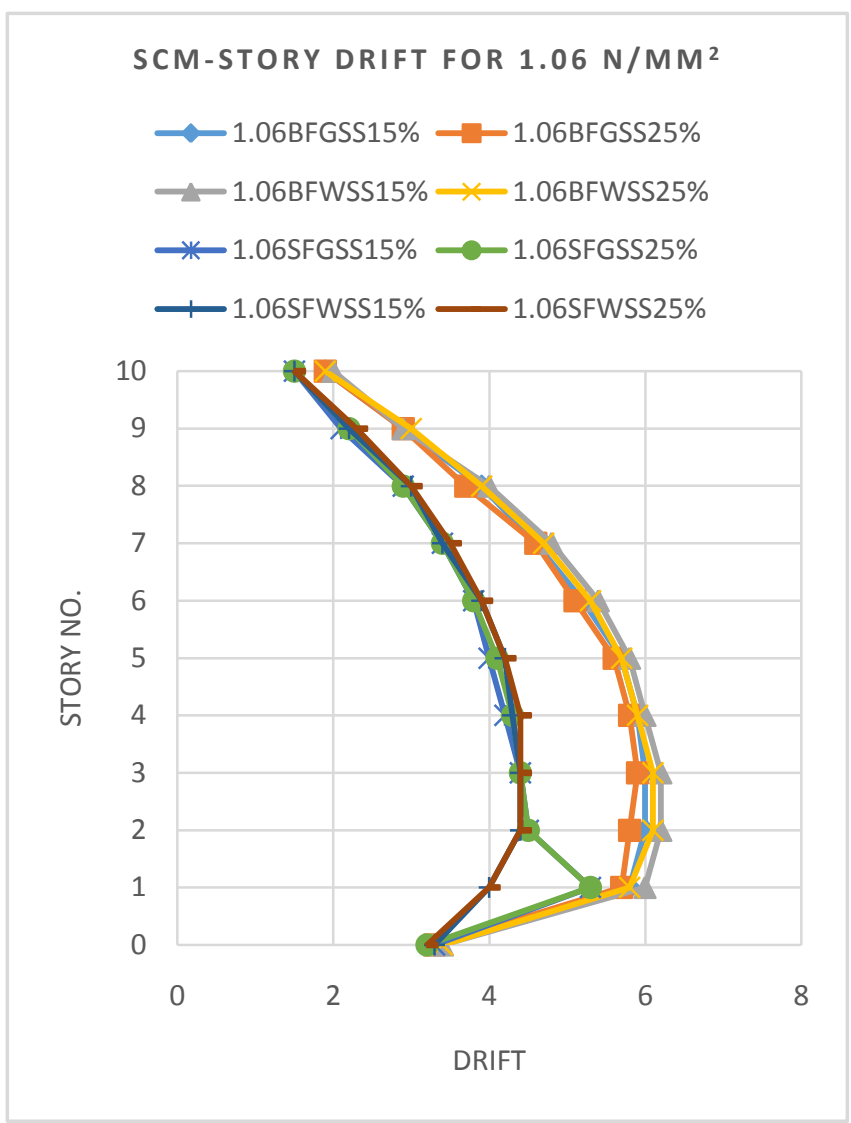

Chart-4: Story Drift for SCM in X direction (1.06) 


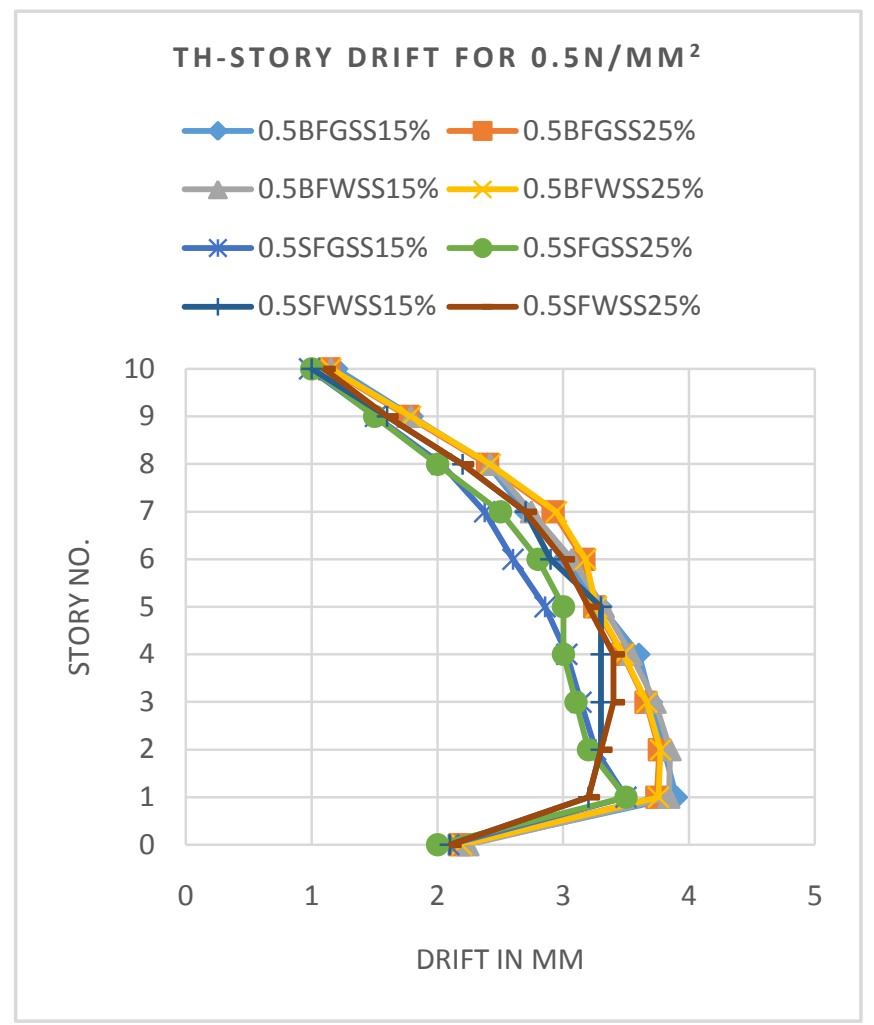

Chart-5: Story Drift for TH in X direction (0.5)

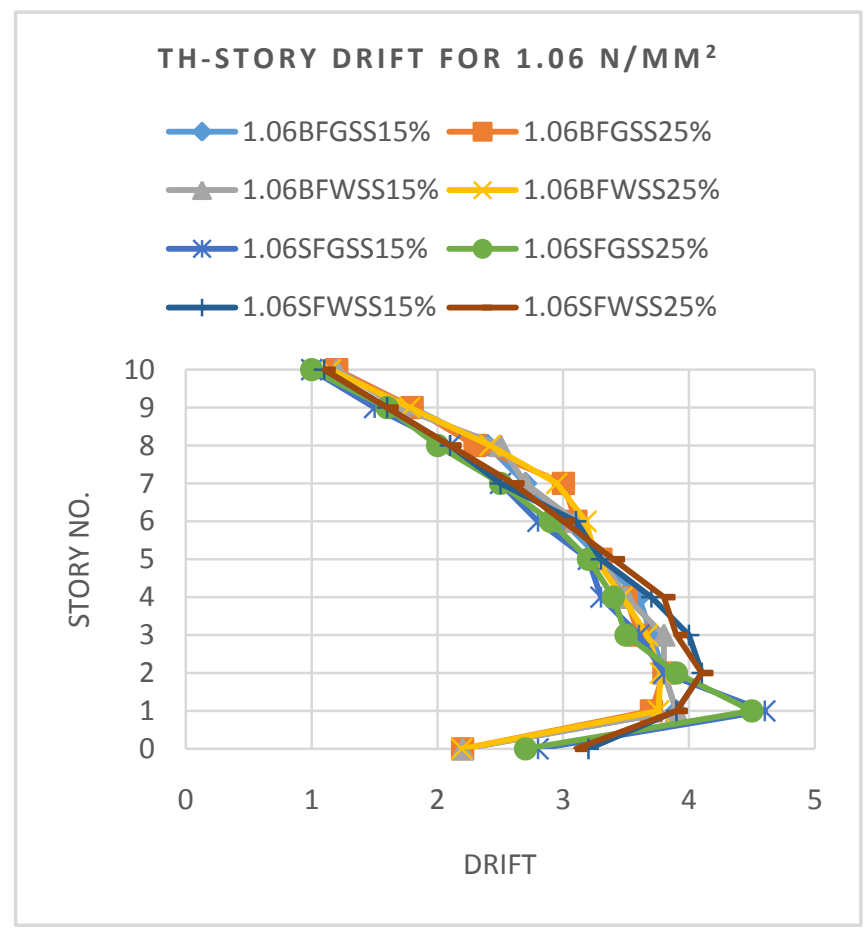

Chart-6: Story Drift for TH in X direction (1.06)

The drift value has a particular importance of serviceability requirement. According to Indian seismic code IS 1893 Part$1: 2002$, The story drift in any story due to the minimum specified design lateral force, with partial load factor of 1.0, shall not exceed $0.004 * \mathrm{~h}$, where $\mathrm{h}=$ story height.
In building with strut, Story drift is less as compared to without considering strut type building in both direction, i.e. and Y.(See Chart 3 to 6). All story drift are found to be within permissible limit i.e. $1.2 \mathrm{~cm}$.

\subsection{Axial Force}

The maximum axial force in the column are as shown in following,

Table 5: Maximum Axial Force (kn) on column at Base in EQ-X

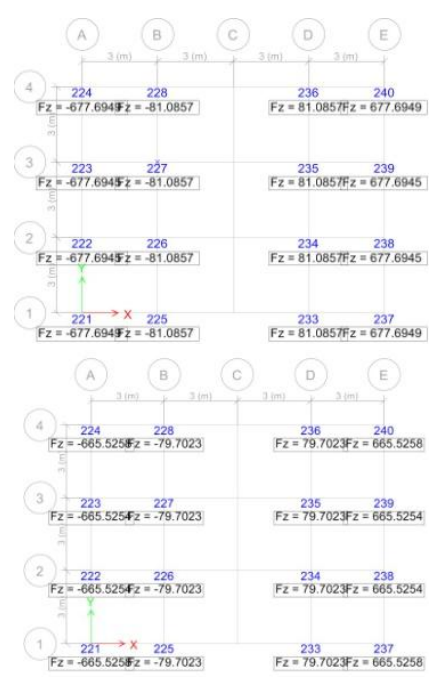

0.5BFGSS15\% \& 1.06BFGSS15\% 0.5BFGSS25\% \& 1.06BFGSS25\%

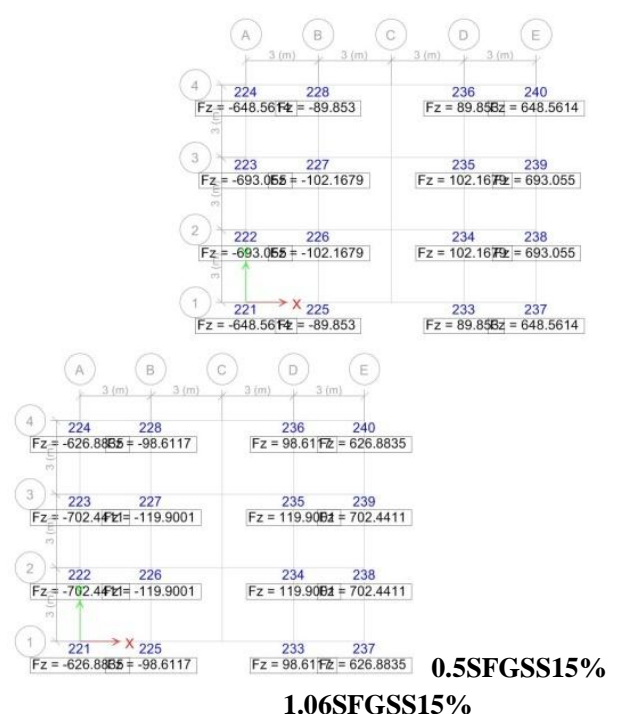




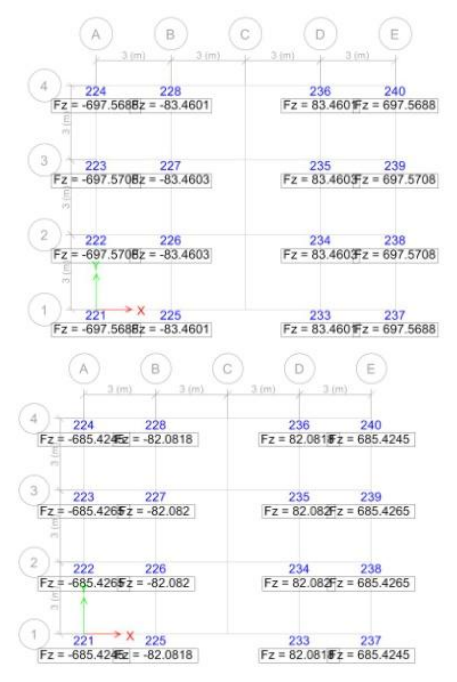

0.5BFWSS15\% \& 1.06BFWSS15\%

0.5BFWSS25\% \& 1.06BFWSS25

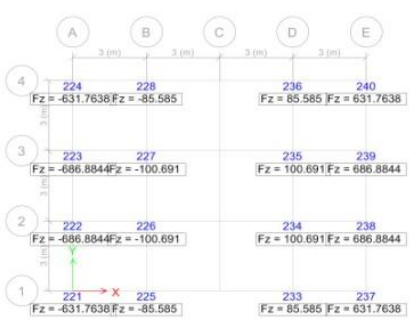
0.5SFGSS25\%

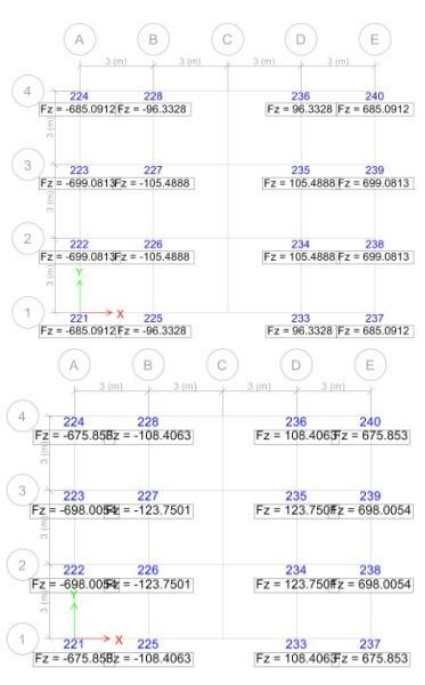

0.5SFWSS15\%

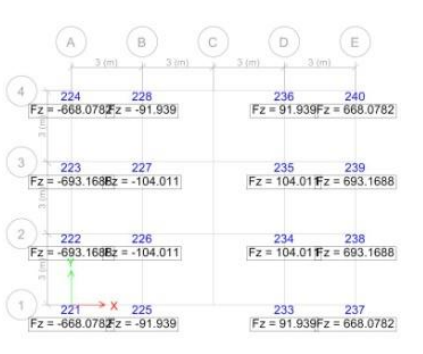

$0.5 \mathrm{SFWSS} 25 \%$

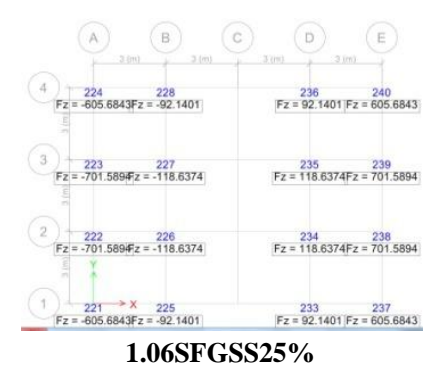

\section{ACKNOWLEDGEMNET}

The author gratefully acknowledge the encouragement and support given by the MS University of Baroda.

\section{REFERENCES}

[1] P. G. Asteris, 2003, M.ASCE, Lateral Stiffness of Brick Masonry In filled Plane Frames, Journal of Structural Engineering, Vol.129, No.8, August1, 2003.ASCE, ISSN0733-9445/2003/8-1071 \pm 1079 .

[2] Panagiotis G. Asteris, Christis Z. Chrysostomou, Ioannis P. Giannopoulos, and Eleni Smyrou, Masonry Infilled Reinforced Concrete Frames With Openings, III ECCOMAS Thematic Conference on Computational Methods in Structural Dynamics and Earthquake Engineering, M. Papadrakakis, M. Fragiadakis, V. Plevris (eds.), Corfu, Greece, 26-28 May 2011

[3] Nehrp Guidelines for the Seismic Rehabilitation of Buildings, FEDERAL EMERGENCY MANAGEMENT AGENCY, FEMA 273 / October 1997, Chap. 7.

[4] Hemant B. Kaushik, Durgesh C. Rai, M.EERI, and Sudhir K. Jain, M.EERI, Code Approaches to Seismic Design of Masonry-Infilled Reinforced Concrete Frames: AState-of-the-ArtReview, Earthquake Spectra, Volume22, No.4, pages 961983, November2006; 2006, Earthquake Engineering Research Institute.

[5] Diptesh Das and C.V.R. Murty, Brick masonry infills in seismic design of RC framed building, The Indian Concrete Journal,July 2004. 
[6] Mohd Danish, Shoeb Masood, Zaid Mohammad, $2^{\text {nd }}$ International Conference on Emerging Trends in Engineering \& Technology, April 12-13, 2013.

[7] BIS, IS1905:1998 Code of practice structural use of unreinforced masonry.

[8] I.S. 1905-1987, Code Of Practice For Structural Use Of Unreinforced Masonry, Bureau of Indian Standards, New Delhi

[9] Indian standard, Code of Practice for Plain and Reinforced Concrete, IS 456: 2000, Bureau of Indian Standards, New Delhi, India.

[10] Indian Standard, Criteria for earthquake resistant design of structures, IS 1893(Part 1): 2002, Bureau of Indian Standards, New Delhi, India.

[11] Murty, C.V.R., and Jain, S.K., 2000. Beneficial influence of masonry infills on seismic performance of RC frame buildings, Proceedings, $12^{\text {th }}$ World Conference on Earthquake Engineering, New Zealand, Paper No.1790.

\section{BIOGRAPHIES}

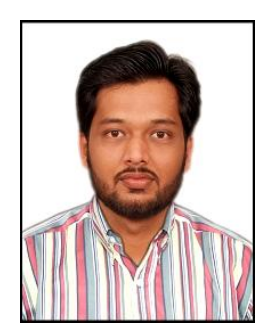

Jinyawala Mohammad Husenibhai is a ME Dissertation student doing his thesis under the guidance of Dr.V. R. Patel from The M. S. University of Baroda. He has done his B.E. in civil engineering from the Indore, RGPV Bhopal university.

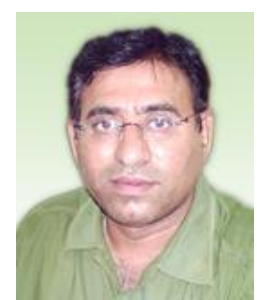

Dr. V. R. Patel is an assistant professor in the Faculty of Technology and Engineering, The M. S. University of Baroda. He has a broad experience in the field of structure engineering. He has also designed more than 2500 projects which includes industrial, High rise building. 